\title{
Od wspomożyciela do wroga — 0 doświadczeniach wspótpracy z policją z perspektywy rodzin osób zaginionych długotrwale
}

\author{
https://doi.org/10.19195/2083-7763.10.15
}

\section{Abstrakt}

Celem artykułu jest opis jakości współpracy pomiędzy Policją a bliskimi osób zaginionych. Współpraca ta rozpoczyna się od ustanowienia wspólnego celu, jakim jest odnalezienie osoby zaginionej. W kontekście badań własnych autorki artykuł omawia zidentyfikowane uprzednio kontrowersje dotyczące jakości formalnego systemu poszukiwań osób zaginionych. Wykorzystany materiał empiryczny pochodzi z wywiadów narracyjnych. W artykule przedstawiono jedynie perspektywę rodzin osób zaginionych. Zidentyfikowano i omówiono trzy podstawowe problemy dotyczące jakości współpracy pomiędzy tymi podmiotami.

Słowa kluczowe: osoby zaginione, rodziny osób zaginionych, policja, system poszukiwań osób zaginionych

\section{Wprowadzenie}

Społeczna uwaga skierowana na działalność policji skupiona jest na ocenie bieżącego poziomu przestępczości, a także poziomu wykrywalności przestępstw. Nie jest to zresztą kierunek nieuzasadniony. Z tej samej bowiem optyki na jakość pracy spogląda kierownictwo resortu spraw wewnętrznych, oczekując niskiego poziomu przestępczości i wysokiej wykrywalności przestępstw, a co za tym idzie - wysokiego poczucia bezpieczeństwa Polaków. Wypełnienie tych oczekiwań służy zarówno wizerunkowi formacji, jak i samym funkcjonariuszom. „Dobre” statystyki są podstawą również indywidualnych gratyfikacji ${ }^{1}$.

${ }^{1}$ A. Siemaszko, Kogo biją, komu kradną. Przestępczość nierejestrowana w Polsce i na świecie, Foatumadacjobogiczne 10, 2020

(C) for this edition by CNS 
Troska o odpowiednio zbierane dane o przestępczości wydaje się nie iść w parze $\mathrm{z}$ troską o dane dotyczące zaginięć osób w Polsce. Jak przyznają praktycy policyjni, „dane o zaginięciach niezmiernie rzadko stają się przedmiotem analiz, nie mają bowiem większego wpływu na oceny stanu porządku i bezpieczeństwa, a tym samym pracy jednostek policji”" 2 .

Efekty takiego stanu rzeczy są widoczne. Wiedza o zjawisku ma w zasadzie charakter jedynie ilościowy, w dodatku wyraźnie ograniczony. Z danych policyjnych trudno odtworzyć rzetelną charakterystykę socjodemograficzną osób zaginionych (stosowane są na przykład niesymetryczne przedziały wiekowe, brak innych zmiennych niż wiek i płeć), aby móc potwierdzić lub obalić hipotezę o strukturalnym wymiarze zjawiska i predestynacji do bycia zaginionym ${ }^{3}$. Również niewiele wiadomo o przyczynach zaginięć. Znaczny udział mają kategorie „inne” (33\% wszystkich zgłoszonych zaginięć w 2017 roku) i „nie określono” (24\%). Występuje także między innymi kategoria „nie ustalono” $(0,08 \%)^{4}$, choć nie jest jasne, czym te dwie ostatnie różnią się znaczeniowo.

Pomimo ubogiej wartości analitycznej danych zastanych wiadome jest, że rokrocznie w Polsce status osoby zaginionej utrzymuje blisko 20 tys. osób. Jednak problematyka zaginięć to nie tylko sami zaginieni. To także osoby im dotychczas najbliższe: rodzina, dalsi krewni, przyjaciele. Uważa się, że zaginięcie jednej osoby ma negatywny wpływ na jakość życia co najmniej dwunastu kolejnych, $\mathrm{z}$ czego jedna trzecia doświadcza problemów natury fizycznej lub psychicznej w związku z zaginięciem ${ }^{5}$. W badaniach australijskich wykazano, że $23 \%$ krewnych i znajomych osób zaginionych wymagało interwencji medycznej, a 22\% doświadczyło poważnego uszczerbku na zdrowiu 6 . Specyfika doświadczenia niejednoznacznej straty przekłada się na zwiększone ryzyko depresji, konfliktów, dysfunkcji w rodzinie i funkcjonowania w szerszym kontekście społecznym.

Wielość zagrożeń i wyzwań, przed którymi stają bliscy osób zaginionych sprawia, że lokują się w wyjątkowo trudnej sytuacji społecznej, realizując przy tym projekt życiowy, mający na celu odnalezienie zaginionego bliskiego. Znaczący

${ }^{2}$ W. Thiel, Zaginięcia osób w Polsce - rozmiary zjawiska, „Kwartalnik Prawno-Kryminalistyczny Szkoły Policji w Pile" 2 (4), 2010, s. 30.

${ }^{3}$ Tego zdania podjęli się między innymi kanadyjscy badacze wykazując, że zjawisko zaginięć osób dotyczy zwykle marginalizowanych zbiorowości, takich jak młodzież, kobiety, rdzenni mieszkańcy, mniejszości etniczne i narodowe, bezdomni oraz bezrobotni. Zob. L. Kiepal, P.J. Carrington, M. Dawson, Missing persons and social exclusion, „Canadian Journal of Sociology” 37 (2), 2012, s. $137-168$.

${ }^{4}$ Dane statystyczne uzyskano od Komendy Głównej Policji na podstawie wniosku o dostęp do informacji publicznej.

${ }^{5}$ M. James, J. Anderson, J. Putt, Missing persons in Australia, Research and Public Policy Series, nr 86, Australian Institute of Criminology, Canberra 2008, s. 72, [za:] M. Henderson, P. Henderson, Missing People: Issues for the Australian Community, Commonwealth of Australia: Australian Institute of Criminology, Canberra 1998.

${ }^{6}$ Ibidem, s. 72.

Forum Socjologiczne 10, 2020

(C) for this edition by CNS 
wkład w realizację tego projektu ma w założeniu wnieść Policja jako formacja bezpieczeństwa i porządku publicznego uprawniona do poszukiwania osób, które na skutek wystąpienia zdarzenia uniemożliwiającego ustalenie miejsca ich pobytu, należy odnaleźć w celu zapewnienia ochrony ich życia, zdrowia lub wolności? W niniejszym opracowaniu przedstawiam (sub)doświadczenia formalnej współpracy pomiędzy policją a rodzinami osób zaginionych długotrwale wyrastające na doświadczeniu zaginięcia bliskiej osoby.

\section{Kontrowersje wokół jakości systemu poszukiwań osób zaginionych}

System poszukiwań osób zaginionych nigdy nie był przedmiotem ożywionej debaty społecznej, podobnie jak samo zjawisko zaginięć osób nie doczekało się dotychczas syntetycznego omówienia na gruncie rodzimej socjologii. Podstawowym dokumentem regulującym policyjną praktykę poszukiwań osób zaginionych jest zarządzenie nr 124 Komendanta Głównego Policji z dnia 4 czerwca 2012 roku w sprawie prowadzenia przez Policję poszukiwania osoby zaginionej oraz postępowania w przypadku ujawnienia osoby o nieustalonej tożsamości lub znalezienia nieznanych zwłok oraz szczątków ludzkich. Precyzuje ono między innymi przebieg przyjęcia zawiadomienia o zaginięciu, kategorie osób zaginionych, czynności, które należy podjąć i przeprowadzić wobec zaginięcia, po nadaniu mu właściwej kategorii. Szczegółowe omówienie i ocena procedur policyjnych nie jest zadaniem socjologa. Dla zarysowania kontekstu przedstawionych w niniejszym opracowaniu doświadczeń rodzin osób zaginionych długotrwale, warto jednak zwrócić uwagę na ekspercką ocenę sytemu poszukiwań osób zaginionych w Polsce.

Według raportu Najwyższej Izby Kontroli Policja stworzyła spójny system poszukiwań. Nie jest on jednak wolny od niedociągnięć. Podczas kontroli przeprowadzonej w 2014 roku wśród 30 jednostek administracyjnych Policji pod uwagę wzięto 421 postępowań poszukiwawczych, co stanowiło $8 \%$ wszystkich poszukiwań wówczas prowadzonych przez jednostki objęte kontrolą. Wśród zarzutów wobec jakości funkcjonowania sytemu wymieniono między innymi niepodejmowanie czynności wynikających z przyjętych procedur, braki w nadzorze nad prowadzonymi czynnościami poszukiwawczymi oraz braki w wyszkoleniu funkcjonariuszy w zakresie poszukiwań osób zaginionych ${ }^{8}$. To właśnie niedostateczne przeszkolenie policjantów było jedną z przyczyn nieprawidłowości związanych z poszukiwaniami osób. Blisko połowa policjantów (47\%) przyznała, że dostęp-

${ }^{7}$ Ustawa z dnia 6 kwietnia 1990 r. o Policji, art. 14.1. (Dz.U. 1990 Nr 30, poz. 179). Warto zwrócić uwagę, że zapis ten jest relatywnie nową nowelizacją. Do niedawna kwestia poszukiwań osób zaginionych nie była regulowana ustawowo, lecz przepisami wewnętrznymi.

${ }^{8}$ Raport Najwyższej Izby Kontroli, Poszukiwanie osób zaginionych, Departament Porządku i Bezpieczeństwa Wewnętrznego, Nr ewid. 5/2015/P/14/042/KPB, s. 9. 
ność do szkoleń w tym zakresie jest niewystarczająca, a jedna trzecia uznała mechanizm szkoleń za zły ${ }^{9}$. Problematyczny aspekt szkoleń został - co prawda - zauważony przez Komendę Główną Policji w 2012 roku, lecz — zdaniem NIK - do czasu kontroli nie podjęto żadnych działań naprawczych ${ }^{10}$. Również głosy płynące bezpośrednio od zainteresowanych sygnalizują wadliwość sytemu poszukiwań. W 2013 roku Fundacja ITAKA (Centrum Poszukiwań Ludzi Zaginionych), przeprowadziła badania ankietowe wśród 324 rodzin będących podopiecznymi fundacji. Wobec policji wysuwano zarzuty takie jak: opieszałość, brak wsparcia psychologicznego, brak zaangażowania, brak współpracy pomiędzy poszczególnymi jednostkami w kraju i za granicą, częsta rotacja policjantów przydzielonych do danego zaginięcia ${ }^{11}$.

Jak się okazuje, nie są to zarzuty typowe jedynie dla polskiego systemu poszukiwań zaginionych. Na problemy w komunikacji z funkcjonariuszami w zakresie dostępu do dokumentacji wskazują także australijskie badania wśród rodzin osób zaginionych ${ }^{12}$. Powszechne wydają się być trudności z dokonaniem wstępnego zgłoszenia, szczególnie dotyczącego nastolatka ${ }^{13}$. Bywa, że bliscy zaginionych są przekonani, że nadmierna nachalność i ciągłe stawianie wymagań wobec funkcjonariuszy finalnie skutkować będzie odizolowaniem się policji od rodziny zaginionego ${ }^{14}$. Brytyjscy krewni zaginionych twierdzą, że poziom i zakres poszukiwań jest niewystarczający, a decyzje policyjne nie zawsze zrozumiałe. Są przekonani, że jako osoby znające najlepiej zaginionego mogą być znacznie bardziej przydatni w policyjnym dochodzeniu ${ }^{15}$. Uniemożliwia to jednak jakość komunikacji i przepływu informacji pomiędzy obiema stronami.

Wobec tak rozpoznanego tła policyjnych poszukiwań osób zaginionych postawiono pytania: Jak przedstawiana jest historia współpracy w narracjach bliskich osób zaginionych? Czy zarzuty wobec funkcjonariuszy ujawnione w badaniach ankietowych Itaki są podobne wśród uczestników moich badań, a jeśli tak, to jak są uzasadniane? W jakim stopniu przedstawiona historia współpracy jest spójna z doświadczeniami australijskich i brytyjskich rodzin osób zaginionych długotrwale?

9 Ibidem, s. 32.

10 Ibidem.

11 Sprawozdanie z działań Fundacji ITAKA, Centrum Poszukiwań Ludzi Zaginionych za 2013 rok, http://www.itaka.org.pl/wp-content/uploads/2015/01/Raportmerytoryczny-2013.pdf (dostęp: 23.08.2019).

12 Supported needs of family and friends of long-term missing persons, Families \& Friends of Missing Persons Unit, NSW Department of Attorney General \& Justice, Sydney 2002, s. 8.

13 Ibidem, s. 9.

14 J. Clark, J. Warbutron, C. Tilse, Missing siblings: seeking more adequate social responses, „Child and Family Social Work" 14, 2009, s. 274-275.

15 H. Parr, O. Stevenson, P. Woolnough, Search/ing for missing people: Families living with ambiguous absence, „Emotion, Space and Society” 19, 2016, s. 69-70. 


\section{Założenia metodologiczne}

Aby uzyskać odpowiedzi na postawione pytania, posłużono się materiałem empirycznym w postaci 12 wywiadów narracyjnych przeprowadzonych z bliskimi osób zaginionych (zdefiniowanymi poprzez więzy krwi oraz związek partnerski: małżeństwo lub kohabitacja trwająca dłużej niż 1 rok do momentu zaginięcia). Narratorzy są bliskimi osób utrzymujących status osoby zaginionej od 4 do 39 lat (w momencie badania).

Ponieważ część spraw dotyczących zaginięć początkowo prowadziła milicja obywatelska, skupiono się na doświadczeniach uczestników badań dotyczących jedynie współpracy z policją, w którą MO została przekształcona w 1990 roku. $\mathrm{W}$ badaniach zastosowano teoretyczny dobór próby, co czyni badania niereprezentatywnymi. Prezentowane wnioski obejmują tym samym jedynie perspektywę uczestników badań.

\section{„Pewno popił, wyśpi się i wróci” — wokół przyjęcia zgłoszenia}

Nadanie sytuacji utraty kontaktu z osobą znaczenia zaginięcia dokonują jej bliscy. To oni kontekstowo decydują o tym, czy nieobecność danej osoby w przestrzeni społeczno-geograficznej wymaga podjęcia instytucjonalnych działań zmierzających do jej odnalezienia. Zwyczajową konsekwencją zdefiniowania sytuacji społecznej jako zaginięcia jest jego zgłoszenie policji. Jest to moment, w którym policja jako profesjonalna instytucja wyposażona w uprawnienia do prowadzenia postępowania w sprawie zaginięcia zostaje włączona w świat społeczny rodziny zaginionego. Bliscy zaginionych potrzebują bowiem wiedzy eksperckiej, profesjonalnych umiejętności i pomocy funkcjonariuszy, żywiąc przekonanie o nieadekwatności własnych zasobów do odnalezienia zaginionego.

Doświadczenia większości uczestników badań związane z przyjęciem przez policję zawiadomienia o zaginięciu osoby są negatywne. Funkcjonariusze dają odczuć, że obawy o zdrowie i życie zaginionego są przez zgłaszających wyolbrzymiane, a zgłaszający czują się lekceważeni.

Trywializowanie przypadków zaginięć dotyczy przede wszystkim zaginięć dorosłych i nastolatków. Wyraża się w przypisywaniu sytuacji intencjonalności i kwestionowaniu zagrożenia bezpieczeństwa. Funkcjonariusze ad hoc wyrokują o udziale zaginionego w przedłużającym się spotkaniu towarzyskim, stanie upojenia alkoholowego czy chęci tymczasowej izolacji od środowiska społecznego, próbując tym samym namówić zgłaszającego na odstąpienie od złożenia zawiadomienia.

Zdarza się, że zgłoszenia zaginięć traktowane są przez funkcjonariuszy z pewną dozą sarkazmu:

Po dwóch latach poszłam na policję, a to dlatego, że musiałam swój status cywilny uregulować i przeprowadzić sprawę rozwodową. Czyli po około dwóch latach już przestałam mieć nadzieję, 
że on nagle wróci i powie: bardzo was przepraszam, miałem ciężki czas i w ogóle wracam [...]. Więc idę na tę policję i mówię, że chciałam zgłosić zaginięcie męża, oni pytają kiedy ten mąż zaginął, ja mówię, że od dwóch lat nie mam z nim kontaktu, a oni pytają czy dopiero teraz się zorientowałam [wywiad $\mathrm{nr} 6]$.

Nadal także zdarzają się odmowy przyjęcia zawiadomienia przed upływem 48 godzin od zaginięcia, choć nie istnieje regulacja, która cezurą czasową warunkowałaby moment rozpoczęcia poszukiwań ${ }^{16}$.

\section{Problematyczne aspekty w relacjach z funkcjonariuszami według bliskich zaginionych}

Zainicjowany przez badanych pierwszy kontakt z policją wykazuje, ich zdaniem, istotne niedociągnięcia, jednak pozytywne oczekiwania wobec dalszej współpracy nie zostają na tym etapie całkowicie pogrzebane. Ze strony bliskich zaginionych deklarowana jest pełna gotowość do współpracy, chęć regularnego kontaktu z funkcjonariuszami prowadzącymi sprawę i przekazywanie każdej nowej informacji, która może przyczynić się do odnalezienia zaginionego. Ścisła współpraca obu stron postrzegana jest jako konieczna dla efektywności poszukiwań. Jak bardzo płonne są to nadzieje, uwidacznia narastający pogląd o iluzoryczności formalnych poszukiwań. Im dłużej bowiem trwają poszukiwania, tym bardziej niepochlebna staje się opinia o działaniach policyjnych.

Narratorzy wskazują na trzy zasadnicze problemy dotyczące jakości współpracy. Pierwszym z nich jest, niesatysfakcjonujący uczestników moich badań, model komunikacji oparty na demonstracji władzy formalnej i sile autorytetu funkcjonariusza. Przewaga funkcjonariusza nad bliskim osoby zaginionej wynikająca z prestiżu zawodu, hierarchii społecznej i umocowania w instytucji państwowej jest podkreślana szczególnie przy próbach podważenia kompetencji. Różny status i dysproporcja władzy prowadzi do licznych nieporozumień. Krewny osoby zaginionej traktowany jest niczym balast, zbyt często domagający się informacji z bieżących poszukiwań, kserokopii służbowych notatek i wglądu do prowadzonej dokumentacji. Krewny przeszkadza, bo uważa, że wie lepiej, podważając tym samym autorytet funkcjonariusza. Próby podpowiedzi, jakie kroki można w procesie poszukiwań podjąć (na przykład pobranie próbek materiału genetycznego DNA od rodziny, organizacja przeszukania danego terenu) odbierane są zazwyczaj jako polemizowanie $\mathrm{z}$ wiedzą i umiejętnościami funkcjonariuszy.

Sprawność komunikacji również pozostawia, zdaniem badanych, wiele do życzenia. Aby móc skontaktować się z funkcjonariuszem prowadzącym sprawę danego zaginięcia, jego bliski musi zatelefonować w odpowiednim, lecz zwykle nieznanym mu terminie na komisariat i liczyć na to, że zastanie go przy telefonie.

16 Zgodnie z zarządzeniem nr 124 KGP, $\$ 3$ pkt 1 , „Policja podejmuje poszukiwania osoby zaginionej niezwłocznie po otrzymaniu informacji o zaginięciu osoby”.

Forum Socjologiczne 10, 2020

(C) for this edition by CNS 
Bezpośrednie próby kontaktu poprzedzone są zwykle kilkugodzinnym oczekiwaniem na przyjęcie. Wraz z upływem czasu kontakt z prowadzącymi sprawę traci na intensywności, a krewni mają poczucie, że o dostęp do kolejnych ustaleń muszą ustawicznie zabiegać:

Dopiero po tym jak ja, z własnej inicjatywy, po jakimś czasie zapytałem się o wyniki tych badań, dopiero wtedy przysłali mi pisemnie odpowiedź. Ale tak, żeby z własnej inicjatywy nas poinformować, to, no nie wiem, w moim odczuciu nie było tego ze strony Policji [wywiad nr 1].

Ponadto, w przeciągu lat upływających od zaginięcia, kilkukrotnie zmieniają się funkcjonariusze prowadzący sprawę, którzy głównie „odgrzewali kotlety” [wywiad nr 8]. Zmiany te nie pociągają za sobą spektakularnych efektów i są oceniane jako „zmiany dla zmian” ( $\mathrm{z}$ wyjątkiem sytuacji typowych — jak przejście danego funkcjonariusza na emeryturę, odejście ze służby itp.).

To wszystko sprawia, że krewni zaginionych muszą wypracować adekwatną strategię komunikacji. Może być to zgoda na zastaną rzeczywistość. Może to być jej brak przy jednoczesnym niepodejmowaniu działań, aby ją zmienić. Wreszcie, może być tak, że poczucie osadzenia $\mathrm{w}$ roli lekceważonego petenta wygeneruje próby wstrząśnięcia funkcjonariuszami. Odbywa się to przez demonstrację znajomości przepisów prawnych i gotowości do przeciwstawienia się bagatelizacji problemu, a także - co szczególnie ma niwelować różnice w dystrybucji władzy - powoływanie się na wpływy i znajomości, które wykorzystane miałyby zaszkodzić funkcjonariuszom. Krewni eksponują własny kapitał społeczny w rozumieniu Pierre’a Bourdieu ${ }^{17}$ i zasady: „nieważne, co wiesz, ale kogo znasz” ${ }^{18}$. Przy zastosowaniu takiej strategii relacje stają się wypełnione arogancją, a początkowa kooperacja przekształca się w konflikt: „Zero grzeczności, uprzejmości. Wtedy dopiero zaczęłam wojnę z nimi" [wywiad nr 5].

Efekty przyjęcia takiej strategii wskazują na funkcjonalny wymiar konfliktu. Owocuje on pobudzeniem aktywności, zwiększeniem motywacji do działania i wzrostem zaangażowania funkcjonariuszy. Zwykle jednak działania zaangażowanego kolektywu rzadko są $\mathrm{w}$ stanie osiągnąć natychmiastowe rezultaty:

I dopiero zadzwoniłam do [miejscowość] do komendy wojewódzkiej i złożyłam skargę. Później ktoś tam zadzwonił, jakiś pułkownik z [miejscowość], bo ktoś ze znajomych się poskarżył. No to już radiowóz stał pod domem, już policjanci byli w gotowości. Ale to już było dużo za późno [wywiad nr 5].

Wykorzystanie sieci znaczących znajomości i kontaktów społecznych przez narratorów przyjmuje czasem formę altruistycznego wymierzania kary czy, inaczej mówiąc, nauczki na przyszłość.

17 Bourdieu definiuje kapitał społeczny jako „sumę zasobów faktycznych lub wirtualnych, które przypadają jednostce lub grupie dzięki posiadaniu trwałej sieci mniej lub bardziej zinstytucjonalizowanych relacji wzajemnej znajomości i uznania" za: P. Bordieu, L.J.D. Wacquant, An Invitation to Reflexive Sociology, Chicago 1992, s. 119.

${ }^{18}$ K. Sierocińska, Kapitał społeczny. Definiowanie, pomiar i typy, „Studia Ekonomiczne” 1, 2011, s. 72.

Forum Socjologiczne 10, 2020

(C) for this edition by CNS 
Nawet jeśli przyjęta strategia ma mniej wojowniczy charakter, kapitał kulturowy funkcjonariuszy oceniany jest krytycznie. To drugi aspekt problematycznej współpracy. W narracjach ujawnia się obraz funkcjonariuszy niewykształconych, niewykwalifikowanych, pozbawionych empatii, myślących nader szablonowo, niewykazujących się inicjatywą, niechętnych do kontaktu czy wręcz przed nim uciekających: „W ogóle brak człowieczeństwa” [wywiad nr 8].

Policja postrzegana jest jako zbiór przypadkowych ludzi, którzy nie do końca zdają sobie sprawę z tego, jak powinni działać, wręcz pozbawionych wyobraźni: „Czy to nie jest bulwersujące, kiedy pani wierzy, że każda minuta może być ważna, że jest śnieg, że jest mróz, a on mi przyjeżdża w galowym mundurze, no bo pani chciała, żeby przyjechać?" [wywiad nr 5]. Zarzuty wobec jakości wykonywanej pracy są poważne i sugerują nie tylko niewiedzę, ale także umyślne pomijanie procedur i wadliwe prowadzenie czynności w myśl redukcji wysiłku wkładanego w pracę. Niepodejmowanie działań poszukiwawczych bądź podejmowanie ich w ograniczonym stopniu tłumaczone jest niedoborami kadrowymi, niewystarczającym zapleczem technicznym, a czasem po prostu brakiem paliwa w służbowych samochodach. Tym samym, w poczuciu pozbawienia jakiejkolwiek pomocy, bliscy zaginionych muszą przenieść poszukiwania na własne barki:

To policja powinna powiedzieć słuchajcie, wykopujemy, robimy. Co ja mam wziąć łopatkę i przekopać pół [miejscowości]? [...] To policja powinna zadziałać właśnie stricte szpitale, miejsca dla osób bezdomnych, ze zdjęciem udać się tam. Nie rodzina, która jest już narażona na wystarczająco dużo niefajnych rzeczy, a oni zostawiają to wszystko rodzinie. Idź sobie załatw, idź sobie zrób, weź wyślij, a może tu, a może tam [wywiad nr 8];

Mówienie, że się odnajdzie, że policja coś robi, to jest nieprawda. Z tego co wiem, bardzo dużo osób działa na własną rękę [wywiad nr 4].

Wreszcie trzeci zidentyfikowany problem dotyczący współpracy z policją, to brak psychologicznego i emocjonalnego wsparcia oferowanego rodzinom zaginionych. Jest to problem ujawniający się nie tyle w osobach funkcjonariuszy, ile w samej formacji i jej zapleczu organizacyjnym. Zarządzenie nr 124 Komendanta Głównego Policji formułuje co prawda przepis o powinności poinformowania przez funkcjonariusza osoby zawiadamiającej o najbliższym punkcie lub kontakcie do organizacji udzielającej pomocy prawnej lub psychologicznej rodzinom osób zaginionych, lecz w wielu przypadkach analizowanych narracji dokument ten nie obowiązywał podczas przyjmowania zawiadomienia o zaginięciu. Mimo to oczekiwania w tym aspekcie ze strony krewnych zaginionych są skierowane bezpośrednio na policję:

Chodzi mi o to, że no wedle moich odczuć, nie ma jakiejś takiej, nie było jakiejś takiej konkretnej pomocy ze strony komisariatu, tutaj z miejscowości, gdzie my mieszkamy. Chodzi [...] przede wszystkim o jakąś tam opiekę psychologiczną [wywiad nr 1];

Nie odczułam tego, żeby oni byli tak mocno zainteresowani i czy by zaproponowali chociażby jakiegoś psychologa. O, też bym wymagała, żeby jak sytuacje są takie kryzysowe w rodzinach, żeby ten psycholog zadziałał [wywiad nr 7].

Forum Socjologiczne 10, 2020

(C) for this edition by CNS 
Oczekiwania krewnych wyrastają na bazie faktu, że w systemie poszukiwań osób zaginionych, to policja jest podmiotem. Jest to pierwsza (a czasem także jedyna) formalna, profesjonalna organizacja, z którą stykają się bliscy zaginionych. To od niej oczekują najwięcej. Zdaniem krewnych zaginionych specjalistyczne wsparcie psychologiczne powinno być oferowane przez policję już na etapie zgłoszenia zawiadomienia o zaginięciu, a także podczas kolejnych, nierzadko obciążających emocjonalnie kontaktów, szczególnie przy wezwaniach na identyfikację zwłok o nieustalonej tożsamości. Brak zaplecza pomocowego utwierdza bliskich zaginionych w przekonaniu o triumfie biurokratycznych procedur nad zwyczajną ludzką życzliwością i wyrozumiałością:

No zero wsparcia totalnie. To mnie najbardziej zabolało. Bo to, że policja spartoczy, to byłam pewna. To są takie nieroby po prostu paskudne. No, ale takie wsparcie, żeby z kimś porozmawiać, z kimś kompetentnym, kto przede wszystkim zna się na temacie [...] [wywiad nr 8].

\section{Podsumowanie}

Ogólne doświadczenia współpracy na linii policja-rodziny osób zaginionych, w perspektywie bliskich zaginionych należy uznać za negatywne. Badania potwierdzają tym samym niepokojący obraz mizernej jakości współpracy sygnalizowany w badaniach ankietowych wśród podopiecznych Fundacji ITAKA.

Sposób prowadzenia czynności poszukiwawczych jest, w ocenie uczestników badania, wadliwy. O ile ocenę tę można tłumaczyć perspektywą laika, a jej nienegocjowalność wzmocnieniem poprzez doświadczenia zapośredniczone (na przykład w postaci medialnych relacji z nieefektywnych poszukiwań innych osób zaginionych), o tyle najbardziej widoczną „miarą” doświadczeń współpracy są aspekty relacyjne.

Relacje pomiędzy funkcjonariuszami a bliskimi osób zaginionych są asymetryczne (a ta asymetryczność jest wyraźnie podkreślana), wpędzające w poczucie zagubienia i bezradności. W konsekwencji powoduje to, że bliscy osób zaginionych ze współpracy z policją wynoszą poczucie krzywdy, niesprawiedliwości i braku zaangażowania. Jest to diagnoza tym bardziej uderzająca, gdy konfrontuje się ją ze szczególną sytuacją społeczną, w której znaleźli się beneficjenci poszukiwawczych usług policyjnych. Wygenerowany przez doświadczanie niejednoznacznej straty (ambiguous loss ${ }^{19}$ ) labilny status społeczny i wiele jego psychospołecznych konsekwencji - by wspomnieć tylko „emocjonalny rollercoaster20” (na poziomie indywidualnym), wyzwania ze zmianą ról, naruszenie historii rodziny (na poziomie środowiska rodzinnego) oraz brak rytuałów, izolację i stygmatyzację (na po-

19 Zob. P. Boss, J.R. Yeats, Ambiguous loss: A complicated type of grief when loved ones disappear, „Bereavement Care” 33 (2), 2014.

${ }^{20}$ J. Clark et al., op. cit., s. 272. 
ziomie społecznym, środowiska zewnętrznego ${ }^{21}$ - wydaje się być niedostrzegalny przez tkankę społeczną policji. Prowadzi to do osłabienia zaufania wobec formacji, a przez to także do innych instytucji państwowych, które są postrzegane jako obce i zrutynizowane. Nie są to postawy korzystne z punktu kreowania wizerunku policji, kiedy „wydajność pracy Policji zależy od wzajemnego zaufania i obywatelskiej chęci współpracy [...]"22.

Typowa historia współpracy z perspektywy narratorów jest porównywalna z profilem współpracy rodzin osób zaginionych $\mathrm{z}$ policją $\mathrm{w}$ środowiskach brytyjskim i australijskim. Może to wskazywać na pewien uniwersalny dyskurs, w którym sprawy zaginięć osób traktowane są jako sprawy „drugiej kategorii”. Są one bowiem pozbawione bezwarunkowego komponentu przestępczego i wydają się najczęściej obejmować przypadki intencjonalnego zerwania kontaktu z najbliższymi ${ }^{23}$, czym nie wpisują się w pierwszoplanowe zainteresowanie organów ścigania.

$\mathrm{Z}$ uwagi na to, że kontakt zgłaszających zaginięcie osoby z policjantami odbywa się według standardowych procedur policyjnych, a praca na rzecz ich dobrostanu emocjonalnego jawi się jako marginalna, korzystne mogłoby okazać się wprowadzenie procedury postępowania $\mathrm{z}$ bliskim osoby zaginionej składającym zawiadomienie. Dobrym przykładem tego rodzaju praktyki jest procedura postępowania Policji z osobą, która doświadczyła przemocy seksualnej ${ }^{24}$ opracowana przez fundację Feminoteka i Biuro Pełnomocnika Rządu do Spraw Równego Traktowania. Zawiera ona wytyczne dotyczące odpowiedniego traktowania zgłaszającego, między innymi zalecenia zaniechania jakichkolwiek komentarzy dotyczących zdarzenia, wyglądu i zachowania, osądzania i oceniania sytuacji, sugestie okazywania empatii, brania pod uwagę stanu emocjonalnego, zachowanie szczególnej wrażliwości, taktu i kultury. Wydaje się, że takie wskazania powinny mieć charakter uniwersalny, a zadaniem funkcjonariusza przyjmującego zawiadomienie czy to od osoby pokrzywdzonej przestępstwem, czy od osoby bliskiej zaginionemu jest przestrzeganie takich uniwersalnych zasad. Wygląda na to, że nie jest to pogląd odosobniony — poradnik dla policjantów dotyczący jakości kontaktu z obywatelem opiera się bowiem na takich wartościach, jak szacunek do siebie i innych, uczciwość i kultura osobista. Idea poradnika

${ }^{21}$ Accompanying the Families of Missing Persons. A Practical Handbook, International Comittee of the Red Cross, Switzerland 2013, s. 60.

22 S. Narębska, Public relations w Policji. Wybrane zagadnienia, Szczytno 2009, s. 8.

${ }^{23}$ Według policyjnych statystyk najczęstszymi określonymi przyczynami zaginięć są (dla roku 2017): ucieczka małoletniego z domu lub placówek o charakterze opiekuńczo-wychowawczych i interwencyjnych, nieporozumienia rodzinne, świadome zerwanie ze środowiskiem.

24 Procedura postępowania policji z osobą, która doświadczyła przemocy seksualnej. Procedura opracowana przez Biuro Pełnomocnika Rządu do Spraw Równego Traktowania na podstawie materiału przygotowanego przez fundację Feminoteka w ramach projektu „Stop gwałtom” współfinansowanego przez Fundację im. S. Batorego. Dostępna w internecie: https://feminoteka.pl/procedura-postepowania-z-osoba-ktora-doswiadczyla-przemocy-seksualnej/ (dostęp: 27.08.2019).

Forum Socjologiczne 10, 2020

(C) for this edition by CNS 
zorientowana jest wprawdzie na interwencje $\mathrm{e}^{25}$, jednak — ponownie - winny być to wskazówki uniwersalne. Wszakże, „to, co nie jest do końca sformalizowane, w mniejszym stopniu podlega rozliczeniu i dlatego zdarza się, że jest lekceważone"26.

W kilku narracjach uczestników moich badań pojawiają się pozytywne przykłady relacji policjant - krewny zaginionego. Niektórzy funkcjonariusze wykazywali się życzliwością i zrozumieniem wobec bliskich zaginionych. W celu utrzymania stałego kontaktu podawali numery prywatnych telefonów komórkowych. Szczególnie ci funkcjonariusze, którzy zostali zaangażowani na dalszym etapie poszukiwań (zwłaszcza policjanci z wojewódzkich zespołów do spraw przestępstw niewykrytych, zwanych medialnie Archiwum X), chętnie wysłuchiwali propozycji działań płynących od rodziny i szczegółowo wyjaśniali, w jakim kierunku obecnie prowadzone są działania. Ci „znaczący” dla moich rozmówców policjanci stawali się z czasem podporą ich przekonania o sensowności dalszych poszukiwań nawet wówczas, gdy tego przekonania zaczynało brakować wśród innych członków rodziny. Były to jednostki etykietowane jako wyjątki, pozytywnie wyróżniające się z masy negatywnie ocenianych funkcjonariuszy. Ich pojawienie się w biografii krewnych zaginionych nie niweluje sumarycznych, negatywnych doświadczeń ze współpracy z policją w poszukiwaniu zaginionych bliskich i wyrastającego na ich podłożu przekonania o ignorowaniu całokształtu sytuacji, w jakiej się znajdują.

\section{Bibliografia}

Accompanying the Families of Missing Persons. A Practical Handbook, International Comittee of the Red Cross, Switzerland 2013.

Boss P., Yeats J.R., Ambiguous loss: A complicated type of grief when loved ones disappear, „Bereavement Care" 33 (2), 2014.

Bourdieu P., Wacquant L.J.D., An Invitatation to Reflexive Sociology, Chicago 1992.

Clark J., Warbutron J., Tilse C., Missing siblings: seeking more adequate social responses, „Child and Family Social Work" 14, 2009.

James M., Anderson J., Putt J., Missing persons in Australia, Research and Public Policy Series, nr 86, Australian Institute of Criminology, Canberra 2008.

Kiepal L., Carrington P.J., Dawson M., Missing persons and social exclusion, „Canadian Journal of Sociology" 37 (2), 2012.

Narębska S., Public Relations w Policji. Wybrane zagadnienia, Szczytno 2009.

${ }^{25}$ Zgodnie z zarządzeniem nr 213 Komendanta Głównego Policji z dnia 28 lutego 2007 roku w sprawie metod i form przygotowania i realizacji zadań Policji w przypadkach zagrożenia życia i zdrowia ludzi lub ich mienia albo bezpieczeństwa i porządku publicznego, interwencja oznacza: „szybkie włączenie się policjanta lub policjantów w tok zdarzenia naruszający normy prawne lub zasady współżycia społecznego i podjęcie działań zmierzających do ustalenia charakteru, rodzaju i okoliczności powstałego zdarzenia oraz przedsięwzięć ukierunkowanych na przywrócenie naruszonego porządku prawnego lub zasad współżycia społecznego".

${ }^{26}$ E. Pietruczuk, M. Dąbrowski, Jakość kontaktu policjanta z obywatelem. Wskazówki dotyczace przeprowadzania interwencji policyjnej. Poradnik dla policjanta, Słupsk 2007, s. 5. 
Parr H., Stevenson O., Woolnough P., Searching for missing people: Families living with ambiguous absence, „Emotion, Space and Society” 19, 2016.

Pietruczuk E., Dąbrowski M., Jakość kontaktu policjanta z obywatelem. Wskazówki dotyczace przeprowadzania interwencji policyjnej. Poradnik dla policjanta, Słupsk 2007.

Procedura postępowania policji z osobą, która doświadczyła przemocy seksualnej, https://feminoteka.pl/procedura-postepowania-z-osoba-ktora-doswiadczyla-przemocy-seksualnej/.

Raport Najwyższej Izby Kontroli, Poszukiwanie osób zaginionych, Departament Porządku i Bezpieczeństwa Wewnętrznego, nr ewid. 5/2015/P/14/042/KPB.

Sierocińska K., Kapitał społeczny. Definiowanie, pomiar i typy, „Studia Ekonomiczne” 1, 2011.

Siemaszko A., Kogo biją, komu kradną. Przestępczość nierejestrowana w Polsce i na świecie, Warszawa 2001, s. 14.

Sprawozdanie z działań Fundacji ITAKA, Centrum Poszukiwań Ludzi Zaginionych za 2013 rok, http://www.itaka.org.pl/wp-content/uploads/2015/01/Raportmerytoryczny-2013.pdf.

Supported needs of family and friends of long-term missing persons, Families \& Friends of Missing Persons Unit, NSW Department of Attorney General \& Justice, Sydney 2002.

Thiel W., Zaginięcia osób w Polsce - rozmiary zjawiska, „Kwartalnik Prawno-Kryminalistyczny Szkoły Policji w Pile" 2 (4), 2010.

Ustawa z dnia 6 kwestia 1990 r. o Policji (Dz.U. 1990 Nr 30 poz. 179).

Zarządzenie nr 124 Komendanta Głównego Policji z dnia 4 czerwca 2012 r. w sprawie prowadzenia przez Policję poszukiwania osoby zaginionej oraz postępowania w przypadku ujawnienia osoby o nieustalonej tożsamości lub znalezienia nieznanych zwłok oraz szczątków ludzkich.

Zarządzenie nr 213 Komendanta Głównego Policji z dnia 28 lutego 2007 r. w sprawie metod i form przygotowania i realizacji zadań Policji w przypadkach zagrożenia życia i zdrowia ludzi lub ich mienia albo bezpieczeństwa i porządku publicznego.

\section{From helper to enemy - the experience of cooperation with the police from the perspective of families of long-term missing persons}

\section{Summary}

The article aims to describe the quality of cooperation between police and missing persons' loved ones. This cooperation starts with the common goal of finding the missing person. As the context of the author's research, the article discusses the already identified controversy concerning the quality of the formal search system for missing persons. The empirical material used for the article was comprised of data collected using a narrative interview method. The article presents only the perspective of missing persons' families. The author revealed issues regarding the acceptance of a missing persons report. Three basic problems regarding the quality of cooperation between families of those missing, and police officers were also identified.

Keywords: missing persons, families of missing persons, police, missing persons searching system 